\title{
PEMBENTUKAN KELEMBAGAAN KELUARGA BERENCANA DI KABUPATEN SUKABUMI DAN KOTA BITUNG
}

\section{INSTITUTIONAL FORMATION OF FAMILY PLANNING IN THE DISTRICT SUKABUMI AND THE BITUNG}

\author{
Moh. Ilham A. Hamudy \\ Badan Penelitian dan Pengembangan (BPP) Kementerian Dalam Negeri \\ Jl. Kramat Raya No. 132 - Senen, Jakarta \\ No. Telp./Faks : +62 213140454 ; HP. +62 82111393927 \\ Email :ilhamhamudy80@gmail.com \\ Dikirim : 10 Desember 2014 Direvisi: 20 Januari 2015 Disetujui: 15 Februari 2015
}

\begin{abstract}
Abstrak
Penelitian ini adalah tentang penyelenggaraan urusan keluarga berencana di daerah. Kendati begitu, penelitian ini berfokus pada pembentukan kelembagaan yang mengurus dan mengatur urusan KB di daerah. Tujuan penelitian ini adalah mendapatkan gambaran utuh peran lembaga KB yang sudah berdiri sendiri dalam mengimplementasikan urusan KB yang sudah diserahkan kepada pemerintah daerah. Dengan menggunakan metode deskriptif dan pendekatan kualitatif, penelitian ini menemukan beberapa hal. Pertama, ada kesan tarik menarik kepentingan (ego sektoral) di antara Kementerian Dalam Negeri dan Badan Kependudukan dan KB Nasional mengenai pembentukan lembaga BKKBD di provinsi, dan kabupaten/kota. Kedua, dua daerah, Kabupaten Sukabumi dan Kota Bitung yang telah membentuk BKKBD memiliki fokus perhatian dalam mendukung keberhasilan program KB. Keempat, integrasi program keluarga berencana ke dalam RPJMD, seperti yang dilakukan Pemerintah Kota Bitung dan Kabupaten Sukabumi, menjamin keberlangsungan program dan dianggarkan dalam APBD. Akhirnya, kajian ini menyimpulkan koordinasi dan sinkronisasi kebijakan KB mesti dilakukan oleh BKKBN dan Kementerian Dalam Negeri.
\end{abstract}

Kata kunci: Ego Sektoral, BKKBD, APBD, dan RPJMD.

\begin{abstract}
This study is about the implementation of family planning $(K B)$ in regional affairs. Nevertheless, this study focuses on the establishment of institutional care and family planning in the area set up. The purpose of this study is to get a complete picture of the role of family planning agencies that had stood alone in implementing family planning matters that have been handed over to the local government. By using the methods of descriptive and qualitative approach, this study found several things. First, there is impression of conflicts of interest (sectoral ego) between Ministry of Home Affairs (MoHA) and National Population and Family Planning Board (BKKBN) on forming a population and family planning (BKKBD) institutions in province, county and city. Second, the two regions, Sukabumi County and Bitung City that have shaped BKKBD has focused attention in supporting the success of family planning programs. Third, the integration of family planning into the regional medium-term development plan, as did the City of Bitung and Sukabumi County, ensure the sustainability of the program and budgeted in the regional budget revenue and expenditure $(A P B D)$.Finally, this study concludes, coordination and synchronization policies on family planning should be done by the BKKBN and MoHA.
\end{abstract}

Keywords: Sectoral Ego; BKKBD; Regional Budget Revenue and Expenditure; and Regional MediumTerm Development Plan.

\section{PENDAHULUAN}

Penelitian tentang Keluarga Berencana (KB) memang cukup banyak menghiasi literatur akademik di negeri ini. Namun, di antara kajian itu kebanyakannya bersifat teknis. Sebut saja, misalnya, kajian yang dilakukan oleh Williamson, et.al (2009); Schwartz J.l, et.al (2002); dan Ijaiya G.T, et.al (2009). Mereka lebih berminat menelaah penggunaan alat kontrasepsi dalam mengendalikan laju pertumbuhan penduduk dan KB. Sementara itu, sarjana lainnya lebih banyak menguraikan KB dari perspektif kebijakan publik secara umum (Palumuleni, 2013; Mitra, 1977; Robinson et.al, 2007; Nwachukwu, 2008; dan Molineaux, et.al, 2000). Meski begitu, tetap saja ulasan teknis tentang alat kontrasepsi masih menyertai pembahasan yang mereka uraikan.

Penelitian keluarga berencana yang meneropong keberadaan lembaga keluarga berencana, khususnya yang mengulas kelembagaan KB di Indonesia masih sangat sedikit, salah satunya 
adalah kajian Shiffman (2004). Dalam kajiannya itu, Shiffman banyak mengulas keberadaan Badan Kependudukan dan Keluarga Berencana (BKKBN) di masa Orde Baru. Selain itu, Shiffman juga membahas pelbagai program dan kegiatan yang dilakukan BKKBN dalam upaya menekan laju pertumbuhan penduduk di Indonesia.

Agak berbeda dengan penelitian yang dilakukan oleh para sarjana yang disebut di atas, penelitian ini berfokus pada kelembagaan $\mathrm{KB}$ di daerah. Penelitian ini berusaha mencandrakan pembentukan kelembagaan KB yang ada di daerah. Ide awal penelitian ini sejatinya bermula pada saat Temu Kader Pengelola dan Pelaksana Program Kependudukan, Keluarga Berencana, dan Pembangunan Keluarga 2014 medio Juni lalu, di mana Kepala Badan Kependudukan dan Keluarga Berencana Nasional (BKKBN) mengemukakan, selama dasawarsa terakhir, upaya menekan angka kelahiran jalan di tempat (Kompas, 12/6/2014). Padahal, Peraturan Presiden RI No 7 Tahun 2005 tentang Rencana Pembangunan Jangka Menengah (RPJM) Tahun 2010-2014 sudah mengamanatkan, program KB Nasional merupakan rangkaian pembangunan kependudukan dan keluarga kecil berkualitas, sebagai salah satu upaya dan langkah yang penting, dalam mencapai pembangunan yang berkelanjutan. Dengan begitu, pembangunan diarahkan sebagai salah satu upaya pengendalian kualitas penduduk, melalui program $\mathrm{KB}$, serta pengembangan dan peningkatan kualitas penduduk, melalui perwujudan keluarga kecil yang berkualitas.

Dalam konteks ini, senyatanya kita pernah berhasil mengendalikan laju pertumbuhan penduduk (LPP) melalui implementasi program keluarga berencana (KB) dengan baik. Data Badan Pusat Statistik (BPS) menunjukkan, pada akhir 2010, jumlah penduduk Indonesia 237 juta jiwa. Jika tidak dikendalikan, penduduk Indonesia tahun 2035 diproyeksikan membengkak 345 juta jiwa. Jadi, ada sekira 100 juta jiwa lebih kelahiran yang dapat dihindari melalui program KB.

Pencapaian program kependudukan dan KB nasional dalam 10 tahun terakhir pun mengalami stagnasi. Total Fertility Rate (TFR) atau angka kelahiran total tidak bergerak pada angka 2,6. Penggunaan kontrasepsi (CPR: contraceptive prevalence rate)) cara modern hanya merangkak naik 0,5 persen selama 5 tahun terakhir, yaitu dari 57,4 persen (2007) menjadi 57,9 persen (2012).

Dulu, program KB masuk dalam Garis-garis Besar Haluan Negara (GBHN) yang disosialisasikan dari pemerintah pusat hingga ke tingkat daerah, bahkan masyarakat. Selain itu, para petugas KB di daerah berperan penting dalam mengurangi pertumbuhan penduduk pada era 1970-1980, karena jumlah mereka cukup memadai secara kuantitas (lihat Shiffman, 2004). Dalam jangka waktu itu, pendapatan per kapita naik dari di bawah 1.000 dollar AS per orang per tahun, menjadi 4.000 dollar
AS per orang tiap tahun. Rata-rata usia harapan hidup tahun 1971 yang hanya 47 tahun, naik menjadi 72 tahun saat ini (BPS, 2014). Tetapi, sekarang, keadaannya berbanding terbalik. Penyuluh KB dan Petugas Lapangan KB (PKB/PLKB) jumlahnya jauh berkurang. Banyak PKB/PLKB yang pindah atau dipindahkan (dipromosikan) untuk menduduki jabatan strutural di lembaga/dinas lain. Kondisi ini memang tidak terelakkan. Mengingat mereka merupakan pegawai daerah. Kewenangan mengenai penempatan, mutasi dan promosinya sepenuhnya ada pada pemerintah daerah (Bupati/Wali Kota).

Kembali ke persoalan KB, sejauh ini, pemerintah memprediksi, jumlah penduduk pada 2035 sebanyak 345 juta orang. Kini laju pertumbuhan penduduk 1,49 persen. Menurut para ahli demografi, jika LPP tidak diturunkan secara signifikan, jumlah penduduk Indonesia pada 2035 diperkirakan 345 juta orang, Jadi, ada beban tambahan 38 juta penduduk (Kompas, 10/6/2014). Indonesia juga masih terbebani dengan permasalahan kualitas penduduk yang rendah. Laporan Pembangunan Manusia UNDP pada 2013 memperlihatkan, Indeks Pembangunan Manusia (IPM) Indonesia berada di posisi 121 dari 187 negara di dunia. Sedangkan dari sisi distribusi penduduk, penyebaran penduduk Indonesia masih belum merata. Jika LPP tidak bisa ditekan, negara harus menyediakan pangan, energi, fasilitas kesehatan, dan pendidikan lebih besar. Itu berarti kesejahteraan rakyat akan kian sulit dicapai dan menjadi beban pembangunan. Bonus demografi diperoleh jika angka kelahiran rendah. Saat ini rata-rata angka kelahiran 2,6, padahal seharusnya bisa 2,1. Jika angka kelahiran tinggi, bonus demografi akan cepat selesai karena beban ketergantungan tinggi lagi. Penyebab kondisi di atas, salah satunya, akibat minimnya perhatian pemerintah daerah terhadap isu KB. Padahal, KB merupakan urusan wajib bagi daerah. Upaya intervensi pemerintah pusat saat ini lebih sulit dilakukan dibandingkan masa lalu karena tidak didukung pemerintah daerah. Cakupan ber-KB tidak meningkat sesuai harapan, angka kelahiran masih di angka 2,6, dan Metode Kontrasepsi Jangka Panjang cenderung turun. Impaknya, Indonesia mengalami pertambahan penduduk yang cukup signifikan. Angka rata-rata kelahiran yang semestinya 2,0 persen pada 2013, ternyata meningkat menjadi 2,6 persen. Lalu laju pertumbuhan penduduk yang mestinya 0,5 persen, ternyata meningkat di atas 1,49 persen (Jurnal Nasional, 15/12/2011).

Oleh karenanya, masalah kependudukan harus menjadi perhatian semua pihak, tidak terkecuali, pemerintah daerah yang memang langsung berhadapan dengan masyarakat. Untuk kembali menggalakkan program KB, pemerintah daerah diharapkan membentuk Badan Kependudukan dan Keluarga Berencana Daerah (BKKBD). Lembaga itu diharapkan mampu berperan mengendalikan jumlah penduduk di daerah melalui program $\mathrm{KB}$ dan 
membangun keluarga yang baik. Tetapi, masalahnya, sejak era otonomi daerah, banyak pemerintah daerah tidak memiliki instansi yang mengurus persoalan $\mathrm{KB}$ secara khusus. Komitmen pemerintah daerah pun dinilai kecil, bahkan makin mengecil. Mengecilnya komitmen itu, khususnya pada awal pelaksanaan otonomi daerah antara lain karena pertimbangan pembiayaan. KB yang dianggap sebagai urusan yang lebih banyak menyedot anggaran. Sejauh ini, data BKKBN menunjukkan, dari 511 kabupaten/kota yang ada di Indonesia hanya 18 saja yang memiliki Badan Kependudukan dan KB secara mandiri. Sisanya digabungkan atau dititipkan ke badan lainnya. Kalau pun ada, sifatnya hanya nyempil di instansi lainnya.

Nomenklatur kelembagaannya pun berbedabeda, kedudukannya hanya setingkat Bidang di salah satu satuan kerja perangkat daerah (Badan/Dinas). Biasanya bergabung dengan Dinas Catatan Sipil atau Badan Pemberdayaan Perempuan dan Perlindungan Anak. Karena itu, wajar jika kemudian program kependudukan dan KB di daerah menjadi terabaikan. Apalagi, di satu sisi, paradigma baru tentang kebijakan kependudukan dan KB mengikut UU No 10 Tahun 1992 tentang Perkembangan Kependudukan dan Pembangunan Keluarga Sejahtera dan UU No 52 Tahun 2009 tentang Perkembangan Kependudukan dan Pembangunan Keluarga ada perbedaan. Paradigma yang terkandung dalam UU No 10 Tahun 1992 berfokus pada Pendewasaan Usia Perkawinan; Pengaturan Kelahiran; Pembinaan Ketahanan Keluarga; dan Peningkatan Kesejahteraan Keluarga. Sementara, dalam UU No 52 Tahun 2009 fokus perhatian ditujukan pada Perencanaan Kependudukan; Pengendalian Kuantitas Penduduk; Pengembangan Kualitas Penduduk; Pelayanan KB/Keluarga Sejahtera; Penurunan Angka Kelahiran; Mobilitas Penduduk; Penduduk Rentan; Pembangunan Keluarga; Penyediaan Data Mikro Kependudukan dan Keluarga.

Fokus perhatian yang berdasar pada paradigma yang terbangun dalam kedua UU itu pada gilirannya memengaruhi beban kerja yang diemban lembaga yang mengurus dan mengatur urusan KB di daerah. Padahal, di sisi lain, urusan kependudukan dan keluarga berencana (KB) sudah diserahkan kepada pemerintah daerah. Adapun pemerintah pusat berkewajiban menetapkan norma, standar, prosedur dan kriteria (NSPK). Sudah ada pembagian tugas yang jelas antara pemerintah pusat, provinsi, dan kabupaten/kota. Hal itu termaktub dalam UU No 32 Tahun 2004 tentang Pemerintahan Daerah berikut turunannya, yaitu PP No 41 Tahun 2007 tentang Organisasi Perangkat Daerah dan PP No 38 Tahun 2007 tentang Pembagian Urusan Pemerintahan antara Pemerintah, Pemerintahan Daerah Provinsi, dan Pemerintahan Daerah Kabupaten/Kota.

Kendati begitu, peraturan tersebut dinilai hanya melahirkan berbagai institusi $\mathrm{KB}$ yang ala kadarnya. Kinerja program tidak membaik, setidaknya jika dilihat dari hasil sensus penduduk 2010. Hasil sensus 2010 menunjukkan, penduduk Indonesia mencapai 237.641.326 jiwa, atau dalam tempo satu dekade, penduduk Indonesia naik lebih dari 30 juta jiwa.

Sejak 2000 hingga 2010 setiap tahun terjadi 3-3,5 juta kelahiran, walau laju pertumbuhan penduduk sudah mengalami penurunan dari 2,32 menjadi 1,49 persen pada 2010. Oleh karenanya, penelitian ini dimaksudkan untuk mendalami urgensi pembentukan BKKBD di provinsi dan kabupaten/kota. Selain itu, penelitian ini juga bertujuan untuk memastikan bahwa dengan dibentuknya BKKBD ada perubahan yang mendasar perihal pengendalian penduduk. Artinya, ada korelasi positif/negatif antara daerah yang memiliki BKKBD dengan keberhasilan program KB di daerah tersebut.

\section{METODE}

Penelitian ini menggunakan metode deskriptif dan dipadu dengan pendekatan kualitatif. Pendekatan kualitatif digunakan untuk menggali pelbagai perspektif tentang pembentukan BKKBD. Adapun metode pengumpulan data dilakukan dengan mewawancarai sejumlah informan dan menelusuri pelbagai dokumen yang terkait, baik yang dikeluarkan oleh BPS, BKKBN, BKKBN Provinsi, BKKBD Kabupaten/Kota yang sudah terbentuk, maupun pemberitaan yang dilansir media massa cetak nasional dan lokal. Sedangkan, asumsi yang coba dibangun adalah berangkat dari pemahaman bahwa agar jumlah penduduk dapat dikendalikan, program KB harus didukung oleh pemerintahan daerah di tingkat provinsi dan kabupaten/kota. Dengan begitu, program KB akan sukses di daerah. Apalagi, program pengendalian penduduk sudah menjadi tanggung jawab masing-masing pemerintah daerah. Jika program KB dikelola oleh instansi khusus, semacam BKKBD, maka program kerja menjadi lebih jelas termasuk sumber daya dan anggarannya tentu disusun tersendiri.

Atas dasar itu penelitian ini memusatkan perhatian pada Kabupaten Sukabumi dan Kota Bitung yang sudah eksis BKKBD-nya. Kedua lokus dipilih karena dianggap sebagai pelopor pembentukan BKKBD dan dianggap berhasil melaksanakan program KB di daerahnya. Berkait dengan hal itu, kajian ini dianggap sangat relevan untuk dilaksakan. Dengan adanya BKKBD, diharapkan ada lembaga yang menangani pembangunan kependudukan (secara kuantitas dan kualitas) oleh institusi khusus. Impaknya, akan ada peraturan daerah pada masing-masing kabupaten/kota, tentu akan ada pula komitmen kepala daerah tentang apa yang harus dicukupi pemerintah daerah dalam mensukseskan program $\mathrm{KB}$ di daerah. Di samping itu, penelitian ini juga sangat penting sebagai bahan masukan kepada Menteri 
Dalam Negeri dalam merespons UU Pemerintahan Daerah yang baru berikut peraturan pendukung lainnya agar sinkron dengan UU No 52 Tahun 2009, khususnya Pasal 54 Ayat 1 yang menyebutkan, "dalam rangka pengendalian penduduk dan penyelenggaraan KB di daerah, pemerintah daerah membentuk Badan Kependudukan dan Keluarga Berencana Daerah yang selanjutnya disingkat BKKBD di tingkat provinsi dan kabupaten/kota”.

\section{HASIL DAN PEMBAHASAN}

Untuk membahasnya, perlu diuraikan beberapa teori yang dijadikan landasan pijak dalam penelitian ini. Menurut Widjaja (2005:17) otonomi adalah penyerahan urusan pemerintahan dari pemerintah pusat kepada pemerintah daerah yang bersifat operasional dalam rangka sistem birokrasi pemerintahan.

Tujuannya adalah mencapai efektivitas dan efisiensi dalam pelayanan kepada masyarakat serta menumbuhkembangkan daerah dalam berbagai bidang, termasuk meningkatkan pelayanan kepada masyarakat, menumbuhkan kemandirian daerah, dan meningkatkan daya saing daerah dalam proses pertumbuhan.

Dengan berotonomi, menurut Rasyid, dkk (2002), ada beberapa keuntungan yang dapat diraih. Pertama, lebih mendekatkan pengambilan keputusan dengan masyarakat yang menjadi sasarannya sehingga operasionalisasi keputusan dapat lebih realistik, efektif dan efisien. Kedua, meringankan beban organiasi pada level yang lebih tinggi sehingga dapat menggunakan waktu, energi dan perhatiannya ke sasaran permasalahan yang lebih srategik.

Ketiga, membina kemampuan bertanggung jawab demi para penerima wewenang pada tingkat yang lebih rendah, sehingga secara langsung menciptakan iklim kaderisasi yang lebih empirik dan sistematik. Keempat, dengan kewenangan yang diterimanya, kebanggan para pengambilan keputusan dan pelaksana keputusan pada tingkat yang lebih rendah akan terbangun karena merasa dipercaya oleh pemerintah yang lebih tinggi.

Dalam konteks otonomi itu, pembagian kewenangan antartingkatan pemerintahan merupakan faktor yang sangat penting dalam hubungan antara pemerintah pusat dan pemerintah daerah. Hal itu dikarenakan, sentralisasi dan desentralisasi dalam suatu bangunan negara sangat ditentukan oleh seberapa jauh kewenangan yang dimiliki oleh pemerintah pusat dan pemerintah daerah. Pendulum sentralisasi dan desentralisasi dapat dikatakan sangat ditentukan oleh cara dan jenis kewenangan yang dimiliki oleh setiap level pemerintahan.

Dilihat dari dimensi cara, penyerahan wewenang dari pemerintah pusat kepada pemerintah daerah dapat dilakukan dengan dua metode (Prasojo dkk, 2006). Pertama, terperinci (ultra-vires doctrine).
Cara ini pada dasarnya digunakan untuk melambangkan situasi di mana pemerintah daerah merinci fungsi secara eksplisit.

Oleh karena itu, tindakan pemerintah lokal di luar daftar ini akan dianggap ultra-vires, yaitu di luar lingkup fungsi yang diperbolehkan. Berdasarkan pelimpahan wewenang dengan rincian ini, daerah otonom hanya berwenang melakukan fungsi-fungsi yang telah ditetapkan dan dirinci terlebih dahulu oleh pemerintah.

Kedua, umum (general competence/open end arrangements). Metode ini merupakan metode dengan pola otonomi luas yang memungkinkan pemerintah daerah untuk mengambil tindakan apapun yang diperlukan di wilayah mereka, contohnya: melindungi warga negara, memberikan pelayanan, dan mengembangkan daerah. Berdasarkan prinsip "general competence", pemerintah daerah bebas untuk mengambil tindakan selama mereka tidak melanggar ketentuan dalam peraturan tingkat yang lebih tinggi.

Kedua cara tersebut tentu memiliki sisi kelemahan dan kekuatan. Menurut cara pembagian open end arrangement, pemerintah daerah memiliki kewenangan yang relatif lebih besar dan kemandirian yang kuat oleh karena kewenangan yang diberikan bersifat terbuka.

Kewenangan-kewenangan yang secara enumeratif tidak dimiliki oleh pemerintah pusat, diberikan kepada pemerintah daerah. Karena itu, dilihat dari luasnya kewenangan yang diberikan, cara pembagian kewenangan dengan open end arrangement memberikan derajat otonomi yang lebih luas kepada daerah.

Sebaliknya, dengan dengan cara ultra vires pembagian kewenangan dilakukan secara enumeratif dan rinci kepada pemerintah daerah. Hal-hal yang tidak disebutkan dalam UU dan/atau PP sebagai kewenangan pemerintah daerah, tetap menjadi kewenangan pemerintah pusat. Jika dilihat dari luasnya kewenangan yang diberikan, maka pambagian kewenangan dengan ultra vires relatif membatasi otonomi yang dimiliki oleh pemerintah daerah.

Jika cara open end arrangement yang dijadikan sebagai basis pembagian kewenangan, maka pengawasan pemerintah pusat terhadap pemerintah daerah haruslah dilakukan secara ketat, karena jika tidak hal ini akan menimbulkan dampak terjadinya fragmentasi administrasi dan pembangunan yang tidak terkoordinasi.

Kalau kita telaah naskah akademik UU No 32 Tahun 2004 tentang Pemerintahan daerah disebutkan, di sana disebutkan, salah dua dari tujuh elemen dasar yang membangun entitas pemerintahan daerah yaitu: urusan pemerintahan dan kelembagaan. Urusan pemerintahan, yaitu kewenangan daerah untuk mengatur dan mengurus urusan pemerintahan yang diserahkan ke daerah. Desentralisasi pada hakikatnya membagi urusan pemerintahan antartingkatan 
pemerintahan; pusat mengerjakan apa dan daerah mengerjakan apa. Elemen dasar yang kedua dari pemerintahan daerah adalah kelembagaan daerah. Kewenangan daerah tidak mungkin dapat dilaksanakan kalau tidak diakomodasikan dalam kelembagaan daerah. Untuk konteks Indonesia, ada dua kelembagaan penting yang membentuk pemerintahan daerah yaitu: kelembagaan untuk pejabat politik yaitu kelembagaan kepala daerah dan DPRD; dan kelembagaan untuk pejabat karier yang terdiri dari perangkat daerah (dinas, badan, kantor, sekretariat, kecamatan, kelurahan dll).

Dalam konteks ini, pembetukan BKKBD merupakan pemenuhan elemen dasar pembangunan entitas pemerintahan di daerah. Terlebih, UU No 32 Tahun 2004 mencoba memperjelas pembagian urusan pemerintahan dan tetap dalam koridor otonomi luas (general competence) yang ada di tingkat daerah baik provinsi maupun kabupaten/kota. PP No 38 Tahun 2007 sebagai turunan dari UU No 32 Tahun 2004 mencoba melakukan pembagian urusan pemerintahan antara Pemerintah Pusat, pemerintahan daerah provinsi dan pemerintahan daerah kabupaten/kota. Ada 31 urusan pemerintahan yang diserahkan ke daerah dalam konsep otonomi daerah yang seluas-luasnya sebagaimana diamanatkan dalam Pasal 18 ayat (5) UUD 1945. Salah satu urusan yang diserahkan kepada daerah itu adalah urusan keluarga berencana.

Hal itu sejalan dengan pendapat Denhardt and Denhardt (2003), dalam paradigma Manajemen Publik Baru bahwa struktur pemerintahan yang baik adalah berkarakteristik desentralistik (decentralized public organization). Artinya, serahkan sebagian urusan pemerintah pusat kepada daerah. Merespons hal itu, mau tidak mau berarti pemerintah daerah perlu membuat sebuah lembaga yang tugasnya mengatur dan mengurus urusan keluarga berencana. Atas dasar itu, maka patutlah lembaga BKKBD dibentuk di daerah sebagai konsekuensi logis penyerahan urusan KB kepada pemerintah daerah.

Namun, di sisi lain, Osborne dan Gaebler (1992) mengajak pemerintah agar memiliki karakteristik desentralistis, ramping, dan berjaringan dengan pasar. Organisasi seperti itu ciri mendasarnya adalah "streamlining agency processes", "disaggregation of large bureaucratic structures into quasi-autonomous agencies", dan "reduce size of government”. Hal ini berarti, struktur organisasi pemerintahan memiliki karakteristik yang dibuat seramping mungkin, semi otonom, dan ukuran organisasi yang dikurangi atau dipangkas. Apalagi Gifford \& Elizabeth Pinchot (1993) juga menyatakan, di era post-industrial sekarang ini karakteristik yang melekat dalam organisasi "bureaucracy" mesti diubah. Prinsip "hierarchical chain of command" mesti diganti dengan prinsipprinsip "vision and values", "self-managing teams", "lateral coordination", "informal networks", "choice", dan "free intraprise".
Masalahnya, bagaimana menyesuaikan organisasi seperti itu dalam praktik pemerintahan di daerah dengan regulasi yang telah ditetapkan pemerintah pusat? Menurut regulasi yang ada, urusan KB sejatinya diurus oleh lembaga teknis daerah. Merujuk PP No 41 Tahun 2007, Lembaga Teknis Daerah merupakan unsur pendukung tugas Kepala Daerah. Lembaga Teknis Daerah memunyai tugas melaksanakan penyusunan dan pelaksanaan kebijakan daerah yang bersifat spesifik. Pembentukannya berdasarkan urusan pemerintahan yang menjadi kewenangan daerah yang terdiri dari urusan wajib dan urusan pilihan, dengan memerhatikan kebutuhan, kemampuan keuangan, cakupan tugas, kepadatan penduduk, potensi, karakteristik serta sarana dan prasarana. Penataan organisasinya harus dilakukan melalui analisis jabatan dan analisis beban kerja. Lembaga Teknis Daerah dalam melaksanakan tugasnya menyelenggarakan fungsi perumusan kebijakan teknis sesuai dengan lingkup tugasnya; pemberian dukungan atas penyelenggaraan pemerintahan daerah sesuai dengan lingkup tugasnya; pembinaan dan pelaksanaan tugas sesuai dengan lingkup tugasnya; dan pelaksanaan tugas lain yang diberikan oleh kepala daerah sesuai dengan tugas dan fungsinya. Jadi, ia berperan sebagai supporting staff.

Dalam praktiknya, Lembaga Teknis Daerah dapat berbentuk Badan, Kantor, dan Rumah Sakit. Lembaga Teknis Daerah yang berbentuk Badan dipimpin oleh Kepala Badan, yang berbentuk Kantor dipimpin oleh Kepala Kantor, dan yang berbentuk Rumah Sakit dipimpin oleh Direktur. Kepala dan Direktur berkedudukan di bawah dan bertanggung jawab kepada Kepala Daerah melalui Sekretaris Daerah. Sedangkan, pembentukan Lembaga Teknisnya dilakukan melalui perumpunan urusan. Perumpunan Bidang pemerintahan pada prinsipnya adalah penggabungan beberapa urusan pemerintahan yang ditangani atau diwadahi pada satu lembaga dengan pertimbangan efisiensi dan efektivitas serta adanya kesamaan dalam penanganan atau pelaksanaan. Perumpunan Bidang pemerintahan yang diwadahi dalam bentuk Dinas tidak dapat menjadi Lembaga Teknis dan sebaliknya, Lembaga Teknis Daerah tidak dapat menjadi Dinas Daerah. Pengembangan dari perumpunan urusan pemerintahan dapat dilakukan dengan pertimbangan prinsip-prinsip organisasi, kebutuhan, ketersediaan potensi dan kemampuan daerah masing-masing.

Penyusunan pun berdasarkan pertimbangan adanya urusan pemerintahan yang perlu ditangani dan merujuk pada urusan pemerintahan yang menjadi kewenangan daerah yang terdiri dari urusan wajib dan urusan pilihan. Pemerintah pusat juga menentukan adanya perumpunan urusan yang berjumlah dua belas macam yang diwadahi dalam bentuk Badan, Kantor, Inspektorat, dan Rumah Sakit. Hal ini berarti lebih menekankan pada dasar pertimbangan pembentukannya adalah berupa 
functional grouping. Dengan begitu, sebisa mungkin urusan keluarga berencana disaturumpunkan dengan urusan lain yang berkenaan, sehingga tidak membengkakkan organisasi perangkat daerah. Itulah sebabnya dalam Peraturan Menteri Dalam Negeri No 57 Tahun 2007 tentang Petunjuk Teknis Penataan Organisasi Perangkat Daerah ditentukan bahwa Badan, Inspektorat dan Lembaga Teknis Daerah (Badan, Kantor dan Rumah Sakit Daerah), yang harus dibentuk sekurang-kurangnya, terdiri atas:

a. Badan Perencanaan Pembangunan Daerah dan Penanaman Modal;

b. Badan/Kantor Kesatuan Bangsa, Politik dan Perlindungan Masyarakat;

c. Badan/Kantor Lingkungan Hidup;

d. Badan/Kantor Ketahanan Pangan;

e. Badan/Kantor Penelitihan, Pengembangan dan Statistik;

f. Badan/Kantor Perpustakaan, Arsip, dan Dokumentasi;

g. Badan/Kantor Pemberdayaan Masyarakat dan Pemerintahan Desa;

h. Badan/Kantor Pemberdayaan Perempuan dan Keluarga Berencana;

i. Badan Kepegawaian dan diklat;

j. Inspektorat;

k. Rumah Sakit Daerah; dan

l. Lembaga Teknis Daerah lainnya sesuai dengan kebutuhan dan kemampuan daerah.

Padahal, seyogyanya, dasar pembentukan Lembaga Teknis Daerah patut memerhatikan kecenderungan yang terjadi pada era sekarang di berbagai negara, yakni dasar pembentukan unit organisasi lebih ditekankan pada pertimbangan market grouping, dalam arti bertumpu pada outputs, produk, services, dan client, bukan lagi functions. Hal itu berarti, dasar pembentukan Lembaga Teknis Daerah seharusnya adalah kebutuhan riil masyarakat akan pelayanan publik. Bukan semata-mata perumpunan urusan tanpa mempertimbangkan besaran urusan, skop, dan kebutuhan riil masyarakat. Dengan begitu, urusan KB tidak mesti disaturumpunkan dengan urusan lain. Tetapi bisa berdiri sendiri dalam sebuah lembaga tertentu mengikut pertimbangan keluaran produk layanan dan fungsi yang dihasilkan.

\section{Sukabumi Menata KB}

Atas dasar itu pemerintah Kabupaten Sukabumi berani mengurus dan mengatur urusan KB secara tersendiri dengan mendirikan satu lembaga tenis daerah yang bernama BKKBD. Alhasil, meski bukan daerah pertama di Indonesia yang mengawali pembentukan BKKBD, bisa dibilang kabupaten ini termasuk daerah yang paling menonjol keberhasilannya dalam mensukseskan program KB di daerah dan menjadi panutan bagi daerah-daerah lain dalam mengelola pelbagai program dan kegiatan KB.
Bagaimana cerita pembentukan BKKBD di Kabupaten Sukabumi ini? Tidak bisa dinafikkan, terbentuknya BKKBD di Kabupaten Sukabumi tidak lain adalah karena kuatnya komitmen sang Bupati. Komitmen kebijakan dan dukungan dalam bentuk anggaran menjadikan transformasi kelembagaan BKKBD di Kabupaten Sukabumi bisa berjalan mulus.

Pemikiran awal Bupati pada 2011 waktu itu adalah penduduk dianggap sebagai aspek yang sangat sentral dan strategis. Upaya pembangunan di bidang lain, sebesar apapun, sehebat apapun, tanpa dibarengi dengan pengendalian penduduk dan KB akan sia-sia.

Tentu bukan hanya pengendalian jumlah yang ditekankan, melainkan juga pembinaan anak sejak lahir hingga dewasa. Mengingat luasnya dimensi kependudukan dan $\mathrm{KB}$, termasuk kompleksnya masalah yang dihadapi, maka perlu penguatan kelembagaan yang fokus menangani kependudukan.

Perlu diketahui, jumlah penduduk Kabupaten Sukabumi menurut data hasil Survei Sosial Ekonomi Nasional saat itu mencapai 2.383.450 jiwa yang terdiri dari 1.214.769 laki-laki dan 1.168.681 perempuan dengan Rasio jenis kelamin sebesar 103,94 yang berarti bahwa dalam 100 penduduk perempuan terdapat sekitar 104 laki-laki.

Kepadatan penduduk Kabupaten Sukabumi adalah sebesar 577 orang per $\mathrm{Km}^{2}$. Menurut data BPS, ditinjau dari kelompok umur, penduduk yang berumur 5-9 tahun dan 10-14 tahun merupakan penduduk yang terbanyak.

Sementara, petugas lini lapangan yang mengurusi pengendalian penduduk dan KB hanya berjumlah 200 orang. Padahal, 15 tahun sebelumnya, dengan jumlah penduduk yang masih sekira 1,6 juta jiwa, Kabupaten Sukabumi memiliki setidaknya 527 petugas PLKB. Hal itu tentu merupakan tantangan dan beban yang tidak ringan bagi pemerintah daerah dalam melaksanakan urusan pengendalian penduduk dan KB. Pembangunan kependudukan dan KB di Kabupaten Sukabumi sejatinya diletakkan dalam konteks pembangunan SDM yang mencakup pembangunan manusia sebagai subyek (human capital), obyek (human resources), dan mencakup seluruh siklus kehidupan manusia (life cycle approach).

Aspek penting dalam konteks itu adalah (a) kuantitas penduduk (b) kualitas penduduk yang berkaitan dengan status kesehatan dan angka kematian, tingkat pendidikan, dan angka kemiskinan (c) mobilitas penduduk, seperti tingkat migrasi yang mempengaruhi persebaran penduduk antarwilayah, antara perkotaan dan perdesaan (d) data dan informasi penduduk, dan (e) penyerasian kebijakan kependudukan.

Memang, senyatanya, Kabupaten Sukabumi berhasil menurunkan angka fertilitas dan peningkatan usia harapan hidup yang berujung pada keberhasilan memasuki transisi demografi. Transisi 
demografi tersebut ditandai dengan menurunnya angka kelahiran dan kematian, dan disertai peningkatan angka harapan hidup.

Hal itu mengubah struktur umur penduduk, yakni menurunnya proporsi penduduk penduduk usia di bawah 15 tahun yang diikuti dengan meningkatnya proporsi penduduk usia produktif (1564 tahun) dan meningkatnya proporsi penduduk usia tua (65 tahun ke atas) secara perlahan.

Kondisi tersebut menyebabkan angka ketergantungan menurun dan mengantarkan Kabupaten Sukabumi memeroleh Bonus Demografi. Bonus Demografi ini merupakan window of opportunity yang bisa menjadi landasan pemicu pertumbuhan ekonomi.

Kendati demikian, Kabupaten Sukabumi masih menghadapi banyak masalah kependudukan, di antaranya adalah:

1. Masih tinggi dan bervariasinya angka kelahiran

2. Bervariasinya angka pemakaian kontrasepsi

3. Masih tinggi dan bervariasinya unmet need

4. Masih rendahnya pengetahuan dan kesadaran remaja dan Pasangan Usia Subur (PUS) tentang KB dan Kesehatan Reproduksi.

5. Masih tendahnya partisipasi keluarga dlam pengasuhan dan pembinaan tumbuh kembang anak dan remaja.

6. Belum optimalnya pemanfaatan kelompokkelompok kegiatan untuk peningkatan, pembinaan, dan kemandirian peserta KB;

7. Belum sinergisnya kebijakan kuantitas, kualitas dan mobilitas, baik secara vertikal maupun horizontal, serta masih terdapatnya kebijakan pembangunan lainnya yang kurang mendukung kebijakan kuantitas penduduk.

Hal itu berdampak pada melambatnya pencapaian sasaran pembangunan kependudukan. Oleh karena penanganan masalah kependudukan melibatkan banyak sektor dan pemangku kepentingan, maka para pemangku kepentingan di Kabupaten Sukabumi wajib berbagi visi, satu tujuan, satu tekad, menuju pembentukan SDM berkualitas dan berdaya saing. Untuk itu, pemerintah daerah berpendapat, harus ada upaya bersama yang saling bersinergi antara semua pemangku kepentingan. Upaya tersebut dikoordinasikan oleh sebuah lembaga yang memunyai tugas antara lain menyerasikan kebijakan kependudukan secara konsisten dan berkesinambungan, mengingat keberhasilan kebijakan kependudukan baru terlihat hasilnya beberapa dekade mendatang, yaitu adanya peningkatan kualitas SDM.

Tanpa lembaga yang kuat, pembangunan kependudukan dianggap sebagai isapan jempol belaka. Proses ini bermula dari keluarga. Misalnya, pasangan itu menikah harus pada saat yang tepat, tidak pada usia dini. Dengan lingkup kerja yang sedemikian banyak dan kompleks, tentu tidak akan bisa ditangani manakala kelembagaannya kurang memadai. Artinya, kelembagaan yang fokus pada persoalan itu ditopang juga oleh ketersediaan personil yang juga memadai dan didukung oleh kelengkapan sarana prasarana serta anggaran adalah sebuah keniscayaan. Meski kelembagaan belum bisa menjadi jaminan. Namun, setidaknya hal itu menjadi modal awal untuk mewujudkan capaian kerja yang dianggapnya kompleks tersebut. Bagaimana supaya penduduk terkendali jumlahnya, kemudian kualitasnya bisa lebih baik lagi, berkelanjutan, itu membutuhkan kelembagaan yang kuat.

Oleh karenanya, Bupati Sukabumi menggalang dukungan dari pelbagai elemen yang ada di Kabupaten Sukabumi sekaligus menyerap masukan dari pihak lain, salah satunya melalui workshop (lokakarya). Lokakarya menjadi ajang bertukar pikiran dengan seluruh pemangku kepentingan, pemerintah daerah lain, dan pemerintah pusat. DPRD pun aktif terlibat dalam penggodokan draft peraturan daerah (Perda) kelembagaan. Dalam melakukan penggodokan Perda, DPRD melalui Badan Musyawarah membentuk pansus. Melalui pansus itulah materi-materi didalami. DPRD melakukan diskusi secara maraton dengan eksekutif. Dari situ DPRD menemukan pemikiran yang sama mengenai pengendalian penduduk. Walaupun sampai hari ini belum ada penjelasan dari PP yang merupakan turunan UU No 52 Tahun 2009, Pemerintah Kabupaten Sukabumi bersama DPRD sepakat untuk melahirkan BKKBD.

Kesepakatan itu tertuang dalam Perda No 25 Tahun 2012 tentang Organisasi Perangkat Daerah Kabupaten Sukabumi dan Peraturan Bupati Sukabumi No 77 Tahun 2012 tentang Struktur Organisasi dan Tata Kerja BKKBD Kabupaten Sukabumi. Berdasarkan dua peraturan itu komposisi struktur organisasi BKKBD terbagi dalam beberapa formasi, yaitu:

a. Kepala Badan

b. Sekretariat, terdiri atas 3 (tiga) Sub Bagian;

c. Bidang Data dan Informasi, terdiri atas 2 (dua) Sub Bidang;

d. Bidang Keluarga Berencana dan Kesehatan Reproduksi, terdiri atas 2 (dua) Sub Bidang;

e. Bidang Keluarga Sejahtera dan Advokasi, terdiri atas 2 (dua) Sub Bidang;

f. Bidang Pengendalian Penduduk, terdiri atas 2 (dua) Sub Bidang;

g. UPTB (unit pelaksana teknis badan), terdiri atas 1 (satu) Sub.Bag TU;

h. Kelompok Jabatan Fungsional

Berbekal lembaga yang mandiri itu Pemerintah Kabupaten Sukabumi dapat dengan leluasa mengembangkan program dan kegiatan KB. Di antara hal yang menonjol yaitu, pertama, pengintegrasian program KB dalam rencana pembangunan jangka menengah daerah (RPJMD), sehingga ada jaminan bahwa program KB dapat dibiayai secara rutin dalam APBD. 
Dalam RPJMD Kabupaten Sukabumi 20102015 terangkum dua program KB yang cukup penting, yaitu CPR. Angka prevalensi pemakaian kontrasepsi atau CPR adalah angka yang menunjukkan berapa banyaknya pasangan usia subur (PUS) yang sedang memakai kontrasepsi pada saat pencacahan dibandingkan dengan seluruh PUS.

Informasi tentang besarnya CPR ini sangat bermanfaat untuk menetapkan kebijakan pengendalian kependudukan dan penyediaan pelayanan KB, baik dalam bentuk mempersiapkan pelayanan kontrasepsi, seperti sterilisasi, pemasangan IUD, persiapan alat dan obat kontrasepsi, serta pelayanan konseling untuk menampung kebutuhan dan menanggapi keluhan pemakaian kontrasepsi. Selain itu, dalam RPJMD tersebut diperhitungkan juga persentase kesertaan ber-KB dari pasangan usia subur (PUS) PraSejahtera dan Keluarga Sejahtera I yang menjadi anggota kelompok Usaha Ekonomi Produktif.

Kedua, pembentukan Kampung KKB (keluarga kecil berkualitas). Keluarga kecil berkualitas yang dimaksud adalah keluarga yang berakhlak mulia, derajat pendidikan dan derajat kesehatannya tinggi, serta memunyai kemampuan daya beli.

Melalui Kampung KKB pembangunan dipusatkan pada penduduk (people-centerd development). Pembangunan pendidikan, kesehatan, dan perekonomian di level mikro diintegrasikan. Muaranya adalah bagaimana meningkatkan derajat pendidikan, kesehatan, dan ekonomi masyarakat. Dan, sejauh ini, Kampung KKB sudah terbentuk di 18 kecamatan dari 47 kecamatan yang ada di Kabupaten Sukabumi.

Kedua, mencegah potensi kelahiran. Hitungannya begini, pada 2012 lalu, data BKKBD Kabupaten Sukabumi menunjukkan, jumlah penduduk di sana mencapai 2.408.827 jiwa. Ratarata jumlah anak yang dilahirkan oleh seorang wanita sampai dengan akhir masa reproduksinya pada periode 2010 sampai 2012 dua anak per seribu wanita. Bila dibandingkan dengan hasil sensus penduduk tahun 2010, dengan jumlah penduduk sebesar 2.341.509 jiwa, maka selama dua tahun telah bertambah penduduk sekira 67.318 jiwa.

Artinya, selama periode dua tahun program pengendalian penduduk dan KB di Kabupaten Sukabumi dapat mengendalikan pertambahan penduduk (kelahiran tercegah) sebanyak 182.031 bayi tertunda untuk lahir, dari potensi kelahiran sebanyak 249.349 bayi yang akan lahir dari PUS yang tidak tercegah.

Dengan tercegahnya kelahiran sebanyak itu, jika dihitung dengan cost and benefit untuk penyediaan pelayanan dasar kesehatan Rp 2.500.000 dan pelayanan pendidikan dasar Rp 3.500 .000 atau Rp 6.000.000 per anak yang lahir, maka beban anggaran pemerintah daerah dan masyarakat di Kabupaten Sukabumi dapat diefisiensikan sebesar
Rp 1.092.186.000.000. Perhitungan ini belum termasuk biaya kebutuhan kesehatan dan pendidikan.

Ketiga, pemerintah daerah memiliki data tentang keluarga yang dipakai semua sektor.Pemerintah Kabupaten Sukabumi melakukan pemetaan profil penduduk dan profil keluarga tiap tahun yang sudah ikut KB dan yang belum. BKKBD memiliki kader-kader yang selalu kontak dengan pasangan usia subur supaya mau ber-KB. Dengan pelbagai program dan kegiatan itu anggaran $\mathrm{KB}$ pun meningkat drastis. Anggaran KB 2012 yang hanya Rp 10,9 milyar, misalnya, meningkat menjadi Rp 20,39 milyar pada 2013.

\section{Pengalaman dari Bitung}

Kota Bitung memiliki cerita tentang $\mathrm{KB}$ dan BKKBD yang tidak kalah menariknya dari Kabupaten Sukabumi. Sebagai salah satu kota yang cukup maju di Sulawesi Utara, senyatanya Kota Bitung menyimpan persoalan KB dan kependudukan yang juga cukup kompleks. Namun, dengan adanya BKKBD di sana, urusan KB dapat diatasi dengan baik. Bagian ini akan mendedahkan hal itu.

Sebagai gambaran awal, secara geografis, Kota Bitung terletak pada posisi $1^{0} 23^{\prime} 23^{\prime \prime}-1^{0} 35^{\prime} 39$ LU dan $125^{0} 143^{\prime \prime}-125^{0} 18$ ' 13 "BT dengan batas-batas wilayah antara lain sebelah utara Kecamatan Likupang (Kabupaten Minahasa Utara dan Laut Maluku), sebelah timur Laut Maluku dan Samudra Pasifik, sebelah selatan Laut Maluku, dan sebelah barat dengan Kecamatan Kauditan (Kabupaten Minahasa Utara).

Wilayah daratan Kota Bitung memunyai luas $313,50 \mathrm{~km}^{2}$ atau $31.350,35$ ha sedangkan luas wilayah perairan $439,8 \mathrm{~km}^{2}$ atau 43.980 ha. Dengan total panjang garis pantai $143,2 \mathrm{~km}^{2}$, terdiri dari 46,3 $\mathrm{km}$ daratan utama dan 96,9 km keliling pulau Lembeh serta pulau-pulau kecil lainnya.

Iklim di kota Bitung hanya terdiri dari dua musim, yaitu musim kemarau dan musim penghujan. Keadaan ini berkaitan erat dengan arus angin yang bertiup di wilayah ini. Pada bulan Oktober sampai dengan April biasanya terjadi hujan karena angin yang bertiup dari arah Barat/Barat Laut banyak mengandung air. Sedangkan pada bulan Juni sampai dengan September biasanya terjadi musim kemarau karena angin yang bertiup dari arah Timur tidak banyak mengandung air.

Mengenai kondisi demografis, jumlah penduduk Kota Bitung menurut sensus penduduk tahun 2010 yang dilakukan oleh BPS berjumlah 187.652 jiwa, terdiri dari laki-laki 96.001 jiwa dan perempuan 91.651 jiwa dan tersebar di 8 (delapan) kecamatan. Bila dibandingkan dengan hasil sensus penduduk pada 2000 lalu, di mana penduduk kota Bitung berjumlah 140.270 jiwa berarti setiap tahun rata-rata pertumbuhan penduduk mencapai hampir 3 persen.

Sementara itu, berdasarkan Data Agregat Kependudukan per kecamatan dari Dinas 
Kependudukan dan Pencatatan Sipil Kota Bitung, jumlah penduduk Kota Bitung Tahun 2012 adalah 219.948 jiwa, yang terdiri dari laki-laki sebanyak 112.732 orang atau (51,25 persen) dan perempuan sebanyak 107.216 orang atau (48,75 persen).

Jumlah dan struktur penduduk seperti itu tentu saja menimbulkan persoalan yang cukup kompleks (Manado Post, 15/7/2014). Sebut saja, misalnya, kemacetan, krisis pangan dan perubahan iklim, sebab jumlah penduduk makin bertambah setiap tahunnya sementara lahan semakin mengecil, sehingga tingkat kebutuhan hidup makin meningkat baik sandang maupun pangan. Untuk mengatasi makin meningkatnya pertambahan penduduk itu, semua program di Kota Bitung harus berwawasan kependudukan.

Salah satu caranya adalah mensukseskan program KB melalui pembentukan lembaga yang mengurus KB. Dulu, di Bitung, sudah terbentuk Badan Keluarga Berencana Pemberdayaan Perempuan (BKB-PP). Pembentukan lembaga itu merujuk pada PP No 41 Tahun 2007, Perda Kota Bitung No 5 Tahun 2002 tentang Perubahan Atas Perda Kota Bitung No 7 Tahun 2000; dan Keputusan Walikota Bitung No 42 Tahun 2008 tentang Rincian Tugas, Fungsi dan Tata Kerja Badan KB dan Pemberdayaan Perempuan Kota Bitung, tertanggal 23 Desember 2008.

BKB-PP Kota Bitung tersebut memiliki tugas pokok yaitu: perencanaan, pengkoordinasian, pembinaan dan monitoring, serta pelayanan telematika dan informasi, pengendalian program, dan peningkatan partisipasi pria, pembinaan remaja, jaminan pelayanan $\mathrm{KB}$, pemberdayaan ketahanan keluarga dan pemberdayaan perempuan. Namun, belakangan, Bidang Pemberdayaan Perempuan di BKB-PP digabung ke Sekretarian Daerah Kota nomenklatur Badan KB dan Pemberdayaan Perempuan Kota Bitung, berubah menjadi Badan Kependudukan dan KB Daerah Kota Bitung.

Pembentukan BKKBD tersebut telah memperkuat perhatian pemerintah Kota Bitung tidak hanya terhadap Program KB tetapi juga Program Kependudukan dan KB sesuai amanat UU No 52 Tahun 2009 tentang Perkembangan Kependudukan dan Pembangunan Keluarga, sebab:

1. Sesuai dengan kedudukannnya sebagai Satuan Kerja Perangkat Daerah yang berada di bawah dan bertanggung jawab kepada Walikota Bitung dan memunyai hubungan fungsional dengan BKKBN, maka tanggung jawab program KB juga menjadi tanggung jawab Walikota.

2. Tugas pokok sangat jelas terarah pada program $\mathrm{KB}$, yaitu melaksanakan tugas pemerintahan di bidang pengendalian penduduk dan penyelenggaraan KB di Kota Bitung.

3. Struktur organisasi sesuai dengan struktur organisasi BKKBN sehingga hubungan fungsional dan pembinaan jelas terstruktur.

4. Sarana, prasarana, dan sumber daya manusia diarahkan pada Program Kependudukan, KB dan Keluarga Sejahtera.

5. Anggaran Program Kependudukan dan KB pun terus mengalami peningkatan sesuai kemampuan daerah dan anggaran ini seluruhnya dimanfaatkan untuk mendukung Program KB.

Pada Tabel 1 menjelaskan tentang Perbandingan Anggaran APBD, Program dan Kegiatan BKB PP dan BKKBD Kota Bitung.Sementara, dari segi struktur, tidak jauh berbeda dengan struktur organisasi BKKBD Kabupaten Sukabumi, berdasarkan dua peraturan itu komposisi struktur organisasi BKKBD Kota Bitung terbagi dalam beberapa formasi, yaitu:

Tabel 1. Perbandingan Anggaran APBD, Program dan Kegiatan BKB PP dan BKKBD Kota Bitung

\begin{tabular}{lllccc}
\hline No & \multicolumn{1}{c}{ Uraian } & \multicolumn{1}{c}{$\begin{array}{c}\mathbf{2 0 1 1} \\
\text { (BKB-PP) }\end{array}$} & $\begin{array}{c}\mathbf{2 0 1 2} \\
\text { (BKB-PP) }\end{array}$ & \multicolumn{1}{c}{$\begin{array}{c}\mathbf{2 0 1 3} \\
\text { (BKKBD) }\end{array}$} & $\begin{array}{c}\mathbf{2 0 1 4} \\
\text { (BKKBD) }\end{array}$ \\
\hline 1 & BTL (Rp) & 3.261 .925 .495 & 2.197 .886 .675 & 3.673 .089 .095 & 3.402 .612 .280 \\
2 & BL (Rp) & 1.287 .940 .000 & 1.581 .587 .000 & 2.004 .042 .500 & 2.152 .291 .000 \\
3 & Total (Rp) & 4.549 .865 .495 & 3.779 .473 .675 & 5.677 .131 .595 & 5.554 .903 .280 \\
4 & Jumlah program & 7 & 15 & 17 & 10 \\
5 & Jumlah kegiatan & 7 & 27 & 26 & 24 \\
\hline \multicolumn{2}{l}{ Sumber: BKKBD Kota Bitung }
\end{tabular}

Bitung; sedangkan Bidang Kependudukan menjadi bagian BKKBD.

Berdasarkan Perda Kota Bitung No 12 Tahun 2012 tentang Organisasi dan Tata Kerja Inspektorat, Badan Perencanaan dan Pembangunan Daerah, Lembaga Teknis Daerah dan Lembaga lain Kota Bitung, dan Peraturan Walikota Bitung No 41 Tahun 2012 tentang Rincian Tugas dan Tata Kerja Badan Kependudukan dan Keluarga Berencana Daerah Kota Bitung, maka sejak Desember 2012 a. Kepala Badan

b. Sekretariat, terdiri atas 3 (tiga) Sub Bagian;

c. Bidang Data dan Informasi, terdiri atas 2 (dua) Sub Bidang;

d. Bidang Keluarga Berencana dan Kesehatan Reproduksi, terdiri atas 2 (dua) Sub Bidang;

e. Bidang Keluarga Sejahtera dan Advokasi, terdiri atas 2 (dua) Sub Bidang;

f. Bidang Pengendalian Penduduk, terdiri atas 2 (dua) Sub Bidang; 
g. UPTB (unit pelaksana teknis badan), terdiri atas 1 (satu) Sub.Bag TU;

h. Kelompok Jabatan Fungsional

Pembentukan BKKBD itu sejatinya adalah respons pemerintah Kota Bitung terhadap terbitnya UU No 52 Tahun 2009. Tidak jauh berbeda dengan Kabupaten Sukabumi, Pemerintah Kota Bitung dan DPRD-nya juga memiliki komitmen yang cukup kuat dalam program pengendalian penduduk dan KB.

Mereka berpandangan, perlunya konsep pembangunan berwawasan kependudukan yang memberikan pemahaman secara bijaksana betapa pentingnya masalah kependudukan dalam pembangunan di Kota Bitung. Penduduk adalah titik sentral pembangunan. Pembangunan yang berwawasan kependudukan dilakukan dan diperuntukkan bagi kesejahteraan penduduk. Artinya, penduduk Kota Bitung adalah pelaku sekaligus penikmat hasil-hasil pembangunan.

Oleh karenanya, pembangunan kependudukan di Kota Bitung diarahkan pada pengendalian jumlah penduduk, pengembangan kualitas penduduk, dan pengarahan mobilitas penduduk sebagai sumber daya manusia, agar menjadi kekuatan pembangunan Kota Bitung yang andal.

Pembangunan kependudukan yang demikian hanya dapat dicapai melalui pengembangan keluarga sejahtera yang pada gilirannya diharapkan mampu melahirkan manusia-manusia Kota Bitung yang berkualitas. Sedangkan, pembangunan keluarga sejahtera melalui gerakan KB diarahkan pada pelembagaan dan pembudayaan norma keluarga kecil bahagia dan sejahtera.

Caranya, melalui melalui program pembinaan dan peningkatan kesertaan ber-KB, sosialisasi kebijakan pengendalian penduduk, meningkatkan ketahanan dan kesejahteraan keluarga melalui didukung oleh kelengkapan sarana prasarana serta anggaran adalah sebuah keniscayaan. Itulah sebabnya, Kota Bitung menyiapkan lembaga khusus yang menangani $\mathrm{KB}$, terpisah dengan lembaga lain yang menangani urusan pemberdayaan perempuan atau pun perlindungan anak.

Waktu masih bergabung dalam lembaga BKB-PP, urusan KB tidak terlalu fokus tertangani. BKB-PP lebih berat kepada urusan pemberdayaan perempuan. Baru ketika sudah berdiri masingmasing, urusan $\mathrm{KB}$ bisa tertangani secara lebih fokus. Hal ini bisa dilihat dalam RPJMD Kota Bitung 2011-2016. Meski BKKBD lahir belakangan setelah RPJMD tersusun, program KB tetap masuk dalam RPJMD.

Setidaknya ada beberapa indikator urusan KB yang terangkum dalam RPJMD Kota Bitung. Di antara indikator itu adalah rata-rata jumlah anak per keluarga, rasio akseptor $\mathrm{KB}$, cakupan pasangan usia subur (PUS) peserta KB aktif, persentase unmet need, jumlah anggota $\mathrm{BKB}$ yang ber-KB, cakupan PUS peserta KB anggota UPPKS, dan rasio PLKB 1 (satu) petugas di setiap dua desa/kelurahan.

Alhasil, meski tidak sehebat pencapaian yang diraih Kabupaten Sukabumi, Kota Bitung bisa dibilang cukup berhasil dibandingkan daerah lain yang sudah memiliki BKKBD sendiri. Hal ini bisa dilihat pada hasil cakupan kegiatan BKKBD sejak awal terbentuk dibandingkan ketika masih berbentuk BKB-PP.

Salah satu prestasi yang membanggakan adalah meningkatnya capaian peserta KB warga masyarakat Kota Bitung sejak 2009 s.d 2013 yaitu pada Tabel 2. Selain itu, dijadikannya program Posyandu Cerdas yang diinisiasi Pemerintah Provinsi Sulawesi Utara dan Kota Bitung menjadi program nasional dan menjadi percontohan posyandu di

Tabel 2. Capaian Peserta KB Baru per Mix Kontrasepsi Tahun 2009 dan 2013 Kota Bitung

\begin{tabular}{cccc}
\hline NO & Jenis KB & Tahun 2009 & Tahun 2013 \\
\hline 1 & IUD & 162 & 153 \\
\hline 2 & MOW & 22 & 78 \\
\hline 3 & MOP & 17 & 4 \\
\hline 4 & KONDOM & 340 & 641 \\
\hline 5 & IMPLANT & 1000 & 426 \\
\hline 6 & SUNTIK & 3547 & 4377 \\
\hline 7 & PIL & 1892 & 1730 \\
\hline Sumber: BKKBD Kota Bitung & &
\end{tabular}

Sumber: BKKBD Kota Bitung

kegiatan Tri Bina Keluarga Balita dan Anak, PIK, Remaja Bina Keluarga Lansia, UPPKS, promosi dan penggerakan kepada masyarakat, serta menyediakan/menyebarluaskan data dan informasi kependudukan dan KB, dengan meningkatkan kualitas pencatatan dan pelaporan.

Kesemua harapan itu memerlukan prasyarat kelembagaan yang mantap. Artinya, kelembagaan yang fokus pada persoalan itu ditopang juga oleh ketersediaan personil yang juga memadai dan seluruh Indonesia, menambah kebanggaan tersendiri. Pos pelayanan terpadu atau posyandu merupakan format lama yang digagas Kementerian Kesehatan (Kemenkes) dan BKKBN.Posyandu ini dalam penerapannya sangat efektif, karena masyarakat seperti bayi, balita, ibu hamil, ibu menyusui yang tinggal di perdesaan atau perkotaan, tetapi sedikit jauh dari puskesmas, bisa mendapatkan pelayanan kesehatan terjangkau. 
Dengan capaian itu, tidak heran kalau Walikota Bitung berhasil menggondol penghargaan Satya Lencana Wira Karya dari Presiden Susilo Bambang Yudhoyono pada 2012 lalu atas komitmen dan jerih payahnya dalam menanggulangi ledakan penduduk melalui implementasi program KB di Kota Bitung.

Di samping itu, dalam mendukung program kependudukan dan pembangunan keluarga guna mewujudkan keluarga sejahtera, BKKBD Kota Bitung menggandeng Tim Penggerak Pemberdayaan dan Kesejahteraan Keluarga (PKK). Kerja sama itu dituangkan dalam Memorandum of Understanding $(\mathrm{MoU}) \quad$ No. 07/HK.104/J/V/2014 dan No 03/ST/PKK.KT/BTG/V/2014.

Kerja sama Tim Penggerak PKK dan BKKBD Kota Bitung dapat dilihat dalam 10 program pokok PKK yang dijabarkan dalam 10 prioritas program yang terdiri dari 57 kegiatan. Pelbagai kegiatan itu di antaranya adalah pelatihan PAUD terintegrasi dengan posyandu gerakan sayang ibu (GSI) melalui pemberdayaan keluarga untuk menurunkan angka kematian ibu, bayi dan balita, serta program peningkatan kesehatan reproduksi bagi remaja.

Lebih jauh lagi BKKBD Kota Bitung juga telah membuat rancangan Rencana Induk (grand design) Kependudukan 2010-2035. Rencana Induk diperlukan untuk membantu menentukan strategi dan arah pembangunan kependudukan di masa depan dengan melihat pola pengendalian kualitas dan kuantitas penduduk, data base kependudukan, dan mobilitas penduduk di Kota Bitung.

\section{Integrasi Program KB dalam RPJMD}

Menelaah dua contoh eksistensi dan peran BKKBD di Kabupaten Sukabumi dan Kota Bitung, dapat ditarik benang merah bahwa keberhasilan keduanya adalah terintegrasinya program $\mathrm{KB}$ dalam RPJMD, yang implementasinya terinci dalam rencana kerja pemerintah daerah (RKPD).Sehingga, penganggarannya pun dapat meluncur rutin setiap tahun dalam APBD.

Hal ini penting guna mengupayakan program kependudukan, keluarga berencana, dan pembangunan keluarga menjadi prioritas dalam rencana pembangunan jangka menengah daerah. Tujuannya adalah harus ada alokasi anggaran yang memadai di bidang kependudukan, KB, dan pembangunan keluarga. Integrasi rencana induk pengendalian kuantitas penduduk dan peningkatan kualitas keluarga ke dalam RPJMD sebagaimana dicanangkan Kota Bitung, misalnya, adalah sebuah keniscayaan.

Tidak bisa dipungkiri, senyatanya, sejak otonomi daerah bergulir, program kependudukan dan KB agak terbengkalai. Desentralisasi program kependudukan dan KB pasca otonomi daerah memberikan dampak yang jelas terlihat pada beberapa parameter kependudukan dan KB, seperti cenderung meningkatnya TFR dan laju pertumbuhan penduduk, menurunnya CPR dan meningkatnya unmet need. Kondisi ini memerlukan penyikapan yang cerdas, terobosan nyata dan dapat memberi manfaat nyata.

Pengintegrasian parameter kependudukan dan KB ke dalam RPJMD merupakan langkah strategis untuk menjamin program kependudukan dan KB akan dilaksanakan dengan baik oleh pemerintah kabupaten/kota yang merupakan ujung tombak keberhasilan program tersebut.

Integrasi itu hakikatnya juga menunjukkan BKKBD concern dalam membuat target-target yang rasional untuk menentukan TFR atau rata-rata angka kelahiran, CPR atau cakupan ber-KB, rata-rata usia perkawinan pertama. Jika indikator-indikator ini masuk dalam RPJMD, maka kelembagaan KB akan diperhatikan, anggarannya pun muncul setiap tahun dalam APBD.

Sebagai perbandingan, potret program KB di Kabupaten Bojonegoro patut juga dijadikan percontohan.Meski belum memiliki BKKBD, Kabupaten Bojonegoro berhasil memasukkan parameter kependudukan ke dalam RPJMD. Parameter kependudukan yang berhasil dimasukkan ke dalam RPJMD Kabupaten Bojonegoro ada 22 indikator, 17 indikator Keluarga Berencana Keluarga Sejahtera dan 5 indikator Pemberdayaan dan Perlindungan Anak.

Adapun 17 indikator tersebut di antaranya yaitu laju pertumbuhan penduduk, TFR, General Fertility Rate, Child Women Ratio, cakupan data mikro keluarga, cakupan PUS menjadi Peserta KB aktif, cakupan PUS ingin ber-KB tidak terpenuhi (unmet need), partisipasi pria dalam kesertaan berKB.

Indikator lainnya adalah cakupan PUS yang istrinya di bawah 20 tahun, cakupan anggota BKB yang ber-KB, cakupan anggota BKR yang ber-KB, cakupan anggota BKL yang ber-KB, cakupan PUS anggota kelompokUPPKS yang ber-KB, cakupan penerima modal kelompok UPPKS, persentase tahapan keluarga sejahtera, rasio PKB/PLKB per desa dan jumlah perjanjian kerja sama dengan mitra kerja.

Pengintegrasian program KB ke dalam RPJMD sehingga dapat selalu dianggarkan dalam APBD sejatinya semakin kuat sebab sudah ada regulasi yang mengaturnya, yaitu Permendagri No 27 Tahun 2014 tentang Pedoman Penyusunan, Pengendalian dan Evaluasi Rencana Kerja Pembangunan Daerah Tahun 2015.

Permendagri itu menyebutkan, dalam rangka peningkatan pelayanan bidang KB dan keluarga sejahtera meliputi jenis pelayanan dasar yang mencakup pelayanan Komunikasi Informasi dan Edukasi Keluarga Berencana dan Keluarga Sejahtera, penyediaan alat dan obat kontrasepsi, dan penyediaan informasi data mikro. 
Peraturan tersebut senafas dengan Peraturan Kepala BKKBN No 55/HK-010/B5 Tahun 2010 tentang standar pelayanan minimal (SPM) Bidang Keluarga Berencana dan Keluarga Sejahtera di Kabupaten/Kota. Dampak positif kedua regulasi itu adalah pemerintah daerah dapat memasukkan pencapaian target indikator SPM Bidang KB ke dalam penyusunan RKPD 2015.

Rincian indikator yang bisa dimasukkan dalam RKPD itu antara lain: 1) Sosialisasi kebijakan pengendalian penduduk melalui perencanaan pengendalian penduduk, kerja sama pendidikan, kependudukan dan analisis dampak kependudukan; 2) Pengembangan peta PUS dan pendataan keluarga di desa; 3) Penyediaan dukungan operasional lini lapangan bagi Kelompok Kegiatan (POKTAN), Petugas Pembantu Lapangan Keluarga Berencana (PPLB)/PLKB dan Institusi Masyarakat Pedesaan (IMP) minimal 12 kali dalam setahun; 4) Rapat koordinasi program Kependudukan, KB dan Pembangunan Keluarga di desa dan kecamatan; dan 5) Penyediaan dukungan operasional dan sumber daya manusia untuk Pusat Pelayanan Keluarga Sejahtera (PPKS) di kecamatan.

\section{Rasa Saling Enggan Mengemuka}

Selain integrasi program KB dalam RPJMD keberhasilan keduanya juga lebih disebabkan oleh komitmen kepala daerah dan kompaknya pemangku kepentingan lainnya dalam mensukseskan program KB di daerah masing-masing.Artinya, inisiatif pemerintah daerah patut diacungi jempol.

Tetapi, sayangnya, pembentukan lembaga KB di daerah lain tidak sebaik di Kabupaten Sukabumi dan Kota Bitung. Alih-alih membantu daerah, peran BKKBN malah tidak banyak terlihat dalam pembentukan BKKBD. Pasalnya, regulasi yang dikeluarkan pemerintah pusat sebagai acuan bagi pemerintah daerah belum berjalan efektif.Justru sebaliknya, BKKBN terkesan menghambat pembentukan BKKBD.

Dari pihak BKKBN, misalnya, tidak terlihat niat sungguh-sungguh dalam memfasilitasi terbentuknya BKKBD. Terbukti, sampai hari ini, NSPK berupa PP atau pun Peraturan Kepala BKKBN dan regulasi lainnya mengenai teknis pembentukan BKKBD belum kunjung diterbitkan.

Padahal, UU yang mengamanatkan pembentukan BKKBD itu sudah keluar sejak September 2009 lalu. Dengan kata lain, sudah lima tahun berlalu tidak ada pergerakan serius dari BKKBN dalam memandu daerah untuk membentuk BKKBD.

Parahnya lagi, BKKBN agaknya enggan melepas kewenangannya. Meski UU No 52 Tahun 2009 sudah menjelaskan secara gamblang eksistensi BKKBN dan BKKBD, implementasi di daerah tidaklah demikian. Di level provinsi nomenklaturnya masih BKKBN dan statusnya masih lembaga vertikal pemerintah pusat di daerah. BKKBN berlindung di sebalik Pasal 117A Ayat 1 Perpres No 3 Tahun 2013 yang menyebutkan, perwakilan BKKBN provinsi berakhir tugasnya sampai terbentuknya BKKBD provinsi maupun kabupaten/kota.

Itulah sebabnya, BKKBN belum menyerahkan semua personil, peralatan, pembiayaan dan dokumentasi kepada pemerintah provinsi sesuai amanat PP No 41 Tahun 2007. Padahal, harusnya BKKBN di provinsi menjadi lembaga horizontal yang otonom dan sepenuhnya dikelola pemerintah daerah. Terlebih lagi secara teoretik pemerintahan, hanya urusan yang sifatnya absolut yang boleh ada di daerah.

Urusan absolutlah yang mengizinkan pemerintah pusat menempatkan perwakilannya di provinsi. Artinya, instansi vertikal boleh ada sepanjang urusan tersebut tidak diserahkan kepada pemerintah daerah dalam rangka dekonsentrasi. Urusan absolut yang dimaksud di sini adalah urusan politik luar negeri, pertahanan, keamanan, yustisi, moneter dan fiskal nasional, dan agama.

Oleh karenanya, BKKBN harus legawa menyerahkan urusan pengendalian penduduk dan $\mathrm{KB}$ kepada pemerintah daerah. Pemerintah provinsi dan kabupaten/kota pun wajib menerima urusan itu secara ikhlas dan menjalankannya dengan penuh tanggung jawab.

BKKBN cukup melaksanakan fungsinya sebagai perumus, pembina, dan pembimbing kebijakan nasional; penetap norma, standar, prosedur, dan kriteria; serta pelaksana advokasi, koordinasi, komunikasi, informasi, edukasi, dan evaluasi di bidang pengendalian penduduk dan penyelenggaraan $\mathrm{KB}$.

BKKBN pun wajib membuat PP tentang Pelaksanaan Perkembangan Kependudukan dan Pembangunan Keluarga, Penyelenggaraan KB, Penyelenggaraan Sistem Informasi Kependudukan dan Keluarga, serta pelbagai peraturan pendukung lainnya. Supaya, implementasi UU No 52 Tahun 2009 dapat berjalan efektif dan efisien.

Celakanya, pemerintah provinsi dan kabupaten/kota juga enggan dibebani urusan pengendalian penduduk dan KB karena dianggap membutuhkan anggaran yang tidak sedikit. Faktanya, baru 18 kabupaten/kota se-Indonesia yang sudah memiliki lembaga khusus yang menangani urusan KB. Kalau pun ada, nomenklaturnya berbeda-beda, kedudukannya pun hanya setingkat Bidang di salah satu satuan kerja perangkat daerah (Badan/Dinas). Biasanya bergabung dengan Dinas Catatan Sipil atau Badan Pemberdayaan Perempuan dan Perlindungan Anak.

Padahal, menempatkan urusan pengendalian penduduk dan KB hanya setingkat Bidang di kabupaten/kota, tidaklah tepat. Sebab, urusan itu tidak kecil apalagi ringan. Sehingga, perlu dinaikkan statusnya menjadi Badan tersendiri. Terpisah dari Dinas Catatan Sipil atau Badan Pemberdayaan Perempuan dan Perlindungan Anak. 


\section{Kontroversi Surat Edaran}

Di lain pihak, Kementerian Dalam Negeri (Kemendagri) sebagai pembina pemerintahan di daerah cenderung membatasi gerak daerah dalam membentuk BKKBD. Sementara, urusan pengendalian penduduk dan keluarga berencana (KB) sudah sepenuhnya diserahkan kepada pemerintah daerah. Sudah ada pembagian tugas yang jelas antara pemerintah pusat, provinsi, dan kabupaten/kota.

Hal itu termaktub dalam UU No 32 Tahun 2004 tentang Pemerintahan Daerah berikut turunannya, yaitu PP No 41 Tahun 2007 tentang Organisasi Perangkat Daerah dan PP No 38 Tahun 2007 tentang Pembagian Urusan Pemerintahan antara Pemerintah, Pemerintahan Daerah Provinsi, dan Pemerintahan Daerah Kabupaten/Kota.

Pembatasan itu tampak dari adanya Surat Edaran (SE) Mendagri No 470/541/SJ, tertanggal 12 Februari 2010 yang menyatakan, tugas BKKBD hanya melaksanakan pengendalian penduduk dan menyelenggarakan urusan KB. Sedangkan di luar urusan tersebut merupakan kewenangan dan tanggung jawab Dinas Kependudukan dan Pencatatan Sipil.

Bahkan, Mendagri mengeluarkan lagi SE No 061/1259/SJ tertanggal 7 April 2011 tentang Penataan Kelembagaan Perangkat Daerah Bidang KB dan Pemberdayaan Perempuan yang ditujukan kepada Gubernur, Bupati, dan Walikota seIndonesia, yang diperkuat dengan SE Mendagri No 061/294/SJ, tanggal 1 Februari 2012 yang intinya berisi dua perintah.

Pertama, urusan pengendalian penduduk dan KB tetap dimasukkan dalam rumpun urusan pemberdayaan perempuan dan perlindungan anak. Sehingga, urusan tersebut "cukup” ditangani oleh struktur organisasi setingkat Bidang di Badan Pemberdayaan Perempuan dan Perlindungan Anak.

Kedua, penataan kelembagaan perangkat daerah bidang Keluarga Berencana dan Pemberdayaan Perempuan menunggu selesainya revisi UU No 32 Tahun 2004 dan PP No 41 Tahun 2007. Melalui SE itu Kemendagri bersikukuh menyaturumpunkan urusan KB dengan urusan lain, seperti pemberdayaan perempuan, perlindungan anak atau pun catatan sipil.

Impaknya, pemerintah daerah merespons SE itu dengan serius. Sebagai contoh, di Jawa Tengah, misalnya, Sekda Provinsi menerbitkan SE No 060/21499/2011, tanggal 16 Desember 2011, yang meminta kabupaten/kota agar menangguhkan penataan organisasinya sampai ada revisi UU No 32 Tahun 2004 dan PP No 41 Tahun 2007. Alhasil, tidak satu pun pemerintah kabupaten/kota di Provinsi Jawa Tengah yang memiliki BKKBD.

\section{KESIMPULAN}

Secara umum, pembentukan lembaga yang mengurus dan mengatur urusan $\mathrm{KB}$ di daerah (BKKBD) memiliki urgensi yang patut dipertimbangkan. Uraian di atas juga menunjukkan, dengan dibentuknya BKKBD ada perubahan yang mendasar perihal pengendalian penduduk. Artinya, ada korelasi positif antara daerah yang memiliki BKKBD dengan keberhasilan program KB di daerah tersebut, sebagaimana ditunjukkan Kota Bitung dan Kabupaten Sukabumi.

Tetapi di sisi lain, gambaran di atas juga menjelaskan, dengan adanya BKKBD, ada kesan Kemendagri keberatan dengan institusi di daerah yang menggunakan terminologi kependudukan yang sudah diklaim menjadi milik Ditjen Kependudukan dan Catatan Sipil yang sudah ada di Kemendagri. Meski secara substansi, BKKBD dan Dinas Kependudukan dan Catatan Sipil (sebagai perpanjangan tangan Ditjen Kependudukan dan Catatan Sipil) dapat saling bekerja sama.

Sementara, di lain pihak, BKKBN sendiri terkesan tidak bersemangat untuk mempercepat koordinasi dengan institusi pusat lain, khususnya Kemendagri agar segera melepas penyanderaan atas kelahiran lembaga BKKBD. Tidak tampak program dan kegiatan BKKBN yang sistematis dan proaktif untuk mendorong lahirnya lembaga BKKBD yang akan menjadi ujung tombak pelaksanaan program $\mathrm{KB}$, terutama di kabupaten/kota.

BKKBN pun selayaknya bertanggung jawab terhadap UU No 52 Tahun 2009 yang sejatinya masih memerlukan petunjuk teknis pelaksanaan. BKKBN harus sesegera mungkin mengeluarkan PP dan Peraturan Kepala BKKBN tentang Pembentukan BKKBD agar pemerintah daerah tidak gamang berdiri di antara dua sikap dan kebijakan yang telah dikeluarkan BKKBN dan Kemendagri.

Adapun SE Mendagri yang dipersoalkan seyogyanya tidak perlu keluar seandainya ada niat serius Kemendagri, BKKBN, dan Kementerian Pemberdayaan Perempuan untuk dapat duduk bersama membincangkan persoalan tersebut seraya mencari solusi terbaik atas pembentukan BKKBD itu.

Di lain pihak, pemerintah provinsi dan kabupaten/kota bersama DPRD semestinya merespons amanat UU No 52 Tahun 2009 dengan segera membentuk BKKBD di bawah komando masing-masing kepala daerah dan tetap berkoordinasi dengan BKKBN. Kepala daerah dan DPRD harus punya komitmen yang kuat dalam mengatur dan mengurus urusan pengendalian penduduk dan $\mathrm{KB}$.

Sebab, bagaimana pun juga, pemerintah daerah bertanggung jawab meningkatkan kualitas program dalam memenuhi hak-hak reproduksi, kesehatan reproduksi, pemberdayaan keluarga, pengentasan penduduk miskin, peningkatan 
kesejahteraan anak, pemberdayaan perempuan dan pengendalian kelahiran. Agar, terwujud keluarga kecil yang bahagia, sejahtera, dan berkualitas bagi seluruh warga masyarakat.

Untuk itu, BKKBN dan Kemendagri harus dapat bergandengan tangan dalam mensukseskan program KB di daerah. Tidak perlu ada pertentangan ego sektoral di dalamnya. Sebab, regulasi yang dikeluarkan oleh BKKBN dan Kemendagri (UU dan PP) sudah seiring sejalan. Keduanya sama-sama menginginkan urusan KB didesentralisasikan kepada daerah. Sehingga, sudah sepatutnya BKKBN dan Kemendagri mendorong dan memfasilitasi terbentuknya BKKBD.

Kerja sama ini bisa dimulai dengan mengawal draf UU Pemerintahan Daerah yang baru. Pertama, Kemendagri dan BKKBN mesti bersepakat memasukkan urusan KB diikuti pembentukan kelembagaan dengan menyisipkannya ke dalam Pasal 97 Ayat 3 dari draf UU Pemerintahan Daerah yang sedang digodok pemerintah dan DPR. Dengan begitu ada jaminan urusan KB sinkron dengan UU.

Kedua, dalam rangka penataan organisasi di daerah, BKKBN dan Kemendagri patut menyusun petunjuk teknis dan mengajukan rancangan PERMENDAGRI tentang Pedoman Pembentukan Badan Kependudukan dan Keluarga Berencana Daerah (BKKBD). Apalagi, memang tidak ada klausul dalam UU No 52 Tahun 2009 yang mengamanatkan pembuatan regulasi di bawah UU sebagai petunjuk teknis pembentukan BKKBD.

Oleh karenanya, merujukPasal 45 PP No 41 Tahun 2007 Ayat (1), dalam rangka melaksanakan tugas dan fungsi sebagai pelaksanaan peraturan perundang-undangan dan tugas pemerintahan umum lainnya, pemerintah daerah dapat membentuk lembaga lain sebagai bagian dari perangkat daerah. Dalam konteks ini, termasuk di dalamnya pembentukan BKKBD.

Sedangkan, organisasi dan tata kerja serta eselonisasi BKKBD ditetapkan oleh Menteri setelah mendapat pertimbangan dari menteri yang menyelenggarakan urusan pemerintahan di bidang pendayagunaan aparatur negara. Hal ini dilakukan guna mewadahi penanganan tugas-tugas pemerintahan umum yang harus dilaksanakan oleh pemerintah daerah, namun untuk pengendaliannya, pembentukan BKKBD harus dengan persetujuan pemerintah atas usul kepala daerah.

Di sisi lain, untuk sementara, BKKBN provinsi masih bisa diberikan permakluman untuk berlindung di balik pasal 117A Perpres No 3 Tahun 2013 dalam mempertahankan eksistensinya sebagai instansi vertikal sampai BKKBD terbentuk di kabupaten/kota. Tetapi, dengan catatan, BKKBN provinsi wajib secara gencar melakukan tiga hal.

Pertama, melakukan sosialisasi diseminasi program kependudukan dan KB kepada Bupati/Walikota beserta jajarannya dalam upaya memberikan informasi-informasi mengenai pentingnya urusan pengendalian penduduk dan KB yang menjadi tanggung jawab Pemerintah Kabupaten/Kota secara de jure maupun de facto berdasar ketetapan hukum yang ada.

Kedua, melakukan intensive meeting dengan DPRD Kabupaten/Kota dalam upaya mengadvokasi program kependudukan dan $\mathrm{KB}$, sehingga masuk dalam rencana pembahasan Perda oleh DPRD. Ketiga, melakukan hearing di DPRD dengan Bupati/Walikota dalam rangka mendapatkan tanggapan secara formal atas masukan-masukan perwakilan BKKBN di Provinsi terhadap pembentukan BKKBD. 


\section{Daftar Pustaka}

Denhardt, Janet V. and Robert B. Denhardt. 2003. The New Public Service: Serving, not Steering. New York: Sharpe Armonk

Gifford and Elizabeth Pinchot. 1993. The End of Bureaucracy \& the Rise of the Intelligent Organization. San Francisco, CA: BerretKoehler Publishers, Inc

Ijaiya G.T’; Raheem U. A. Olatinwo A. O; Ijaiya M.A and Ijaiya M.A. "Estimating the impact of birth control on fertility rate in Sub-Saharan Africa”.African Journal of Reproductive Health Vol 13 (4) December 2009

Mitra, A. "National Population Policy in Relation to National Planning in India”. Population and Development Review. Vol 3 (3) September 1977

Molineaux, John W. And Paul J. Gertler. "The Impact of targeted Family Planning Program in Indonesia”. Population and Development Review. Vol 26, Supplement: Population and Economic Change in East Asia (2000), pg 61-85

Nwachukwu I.; Obasi O.O. "Use of Modern Birth Control Methods among Rural Communities in Imo State, Nigeria”.African Journal of Reproductive Rights. Vol 12 (1) June 2008

Osborne, David, dan Ted Gaebler. 1992. Reinventing Government: How the Entrepreneurial Spirit Is Transforming the Public Sector. New York: Plume

Palumuleni, Martin E. "Socio-Economic and Demographic Factors Affecting Contraceptive Use in Malawi". African Journal of Reproductive Health. Vol 17 (3) September 2013, pg 91-104
Prasojo, Eko dkk. 2006. Desentralisasi dan Pemerintahan Daerah: Antara Model Demokrasi Lokal dan Efisiensi Struktural. Jakarta: Departemen Ilmu Administrasi UI

Rasyid, Ryaas dkk. 2002. Otonomi Daerah dalam Negara Kesatuan. Yogyakarta: Pustaka Pelajar dan Pusat Pengkajian Etika Politik dan Pemerintahan

Robinson, Warren C. And John A. Ross (eds). 2007. The Global Family Palanning Revolution: Three Decades of Population Policies and Programs. Washington DC: World Bank

Schwartz J.l: Gabelnick H.L. "Current Contraceptives Research". Perspectives on Sexual and Reproductive Health. Vol. 34 (6) May 2002

Shiffman, Jeremy. "Political Management in Indonesia Family Planning Program". International Family Planning Perspectives. Vol 30 (1) March 2004

Widjaja, HAW. 2005. Penyelenggaraan Otonomi di Indonesia. Jakarta: Raja Garfindo Persada

Williamson L.M, ParkesA. Wight D. Petticre M; Hart G. "Limits to Modern Contraceptive Use among Young Women in Developing Countries: A Systematic Review of Qualitative Research". Reproductive Health. Vol 6 (3) July 2009

Otonomi Daerah Gagalkan Program KB (Jurnal Nasional, 15/12/2011)

Program KB Gagal, Penduduk Indonesia 400 Juta Jiwa (Pos Kota, 12/2/2014)

Program KB Jalan di Tempat (Kompas, 12/6/2014)

Awas, Ledakan Penduduk (Manado Post, 15/7/2014) 
36 | Jurnal Bina Praja | Volume 7 Nomor 1 Edisi Maret 2015 : 21 - 36 